外科学 $\square$ Research Note

\title{
Application of Zolazepam-HCl and Tiletamine-HCl to Immobilization of Hokkaido Brown Bear(Ursus arctos yesoensis)
}

\author{
Hifumi TSURUGA ${ }^{1)}$, Katsumi GOHDA ${ }^{2)}$, Tsutomu MANO $^{3)}$ and Hiroshi KANAGAWA ${ }^{4)}$ \\ 1) Southern Hokkaido Wildlife Research Station, Nature Conservation Department, \\ Hokkaido Institute of Environmental Science, Esashi 043-0044, Japan \\ 2) Noboribetsu Bear Park, Noboribetsu 059-0551, Japan \\ 3) Wildlife Section, Nature Conservation Department, \\ Hokkaido Institute of Environmental Science, Sapporo 060-0819, Japan \\ 4) Hokkaido University, Sapporo 060-0818, Japan \\ (1998.7.27 received, 1999.1.20 accepted) \\ エゾヒグマ(Ursus arctos yesoensis)の不動化に対する \\ 塩酸ゾラゼパムと塩酸チレタミンの応用

 \\ 1) 北海道環境科学研究センター道南地区野生生物室 ₹ 043-0044 檜山郡江差町字橋本町 72-1 \\ 2)のぽりベつクマ牧場 テ 059-0051 登別市登別温泉町 224 \\ 3) 北海道環境科学研究セン夕一野生動物科 ₹ 060-0819 札幌市北区北 19 条西 12 \\ 4) 北海道大学 現社北海道獣医師会 $\mathrm{T}$ 063-0804 札幌市西区二十四軒 4 条 5-9-3
}

\begin{abstract}
Twenty captive and 9 wild bears were treated with a mixture of zolazepam- $\mathrm{HCl}$ and tiletamine- $\mathrm{HCl}$ to evaluate effective dosages for immobilization and physiological responses of immobilized bears. Total dose required for effective immobilization were small $(3.52 \pm 1.53 \mathrm{mg} / \mathrm{kg}$ in captive, and $3.75 \pm 1.57 \mathrm{mg} / \mathrm{kg}$ for wild bears), and immobilized bears showed good muscle relaxation and smooth recovery. Accordingly, this mixture of zolazepam- $\mathrm{HCl}$ and tiletamine- $\mathrm{HCl}$ was considered effective for the immobilization of Hokkaido brown bears.
\end{abstract}

Key Words : brown bear, tiletamine- $\mathrm{HCl}$, zolazepam- $\mathrm{HCl}$

Jpn.J.Zoo Wildl.Med. 4(1) : 61-64, 1999

A combination of xylazine hydrochloride (xylazine $-\mathrm{HCl}$ ) and ketamine hydrochloride (ketamine- $\mathrm{HCl}$ ) has been used to immobilize a number of bear species, including the Hokkaido brown bear (Ursus arctos yesoensis) $[1,5,10]$. Although this combination has the advantage of a wide dosage tolerance, the recovery of immobilized animals is slow, and a large volume of drug is needed to immobilize large animals. In addition, at concentrations above 250 $\mathrm{mg} / \mathrm{ml}$, the solution including ketamine- $\mathrm{HCl}$ must be kept warm to avoid crystallization of ketamine $-\mathrm{HCl}$, making it difficult to use in cold weather conditions [6].

A combination of zolazepam hydrochloride (zolaze- 
Hifumi TSURUGA et al.

Table 1. Drug dosages and physiological responses of captive and wild bears

\begin{tabular}{lcc}
\hline Dosage and response & Captive bears (No. of bears) & Wild bears (No. of bears) \\
\hline Body weight $(\mathrm{kg})$ & $263.7 \pm 104.9(20)$ & $61.6 \pm 27.7(9)$ \\
Induction dose $(\mathrm{mg} / \mathrm{kg})$ & $3.52 \pm 1.53(20)$ & $3.75 \pm 1.57(9)$ \\
Volume $(\mathrm{ml} / \mathrm{kg})$ & $0.035 \pm 0.015(20)$ & $0.037 \pm 0.016(9)$ \\
Induction time(min.) & $14.4 \pm 10.5(14)$ & $13.2 \pm 10.3(9)$ \\
Rectal temp. $\left({ }^{\circ} \mathrm{C}\right)$ & $37.1 \pm 0.5(6)$ & $37.9 \pm 0.3(8)$ \\
Respiration rate $(/ \mathrm{min})$. & $16.1 \pm 11.9(11)$ & $15.6 \pm 1.8(9)$ \\
Heart rate $(/ \mathrm{min})$. & $89.0 \pm 14.4(4)$ & $118.3 \pm 20.1(7)$ \\
Total dose $(\mathrm{mg} / \mathrm{kg})$ & $3.81 \pm 1.56(20)$ & $4.69 \pm 1.70(9)$ \\
Handling time(min.) & $\mathrm{NC}$ & $35.4 \pm 14.4(9)$ \\
\hline
\end{tabular}

${ }^{* 1} \mathrm{NC}:$ Not clocked.

pam- $\mathrm{HCl}$ ) and tiletamine hydrochloride (tiletamine $-\mathrm{HCl}$ ) is now commonly used to immobilize the American black bear (Ursus americanus), the grizzly bear (Ursus arctos horribilis) and other wild animals $[2,4,8,9]$. One of the key benefits of this combination is the small volume of drug necessary for immobilization [8]. In this study, we evaluated dosages necessary for immobilization, and physiolog. ical responses of captive and wild Hokkaido brown bears to a mixture of zolazepam- $\mathrm{HCl}$ and tiletamine $-\mathrm{HCl}$.

Twenty bears kept in Noboribetsu bear park and 9 wild bears captured in south western Hokkaido were immobilized with a 1:1 mixture of zolazepam $-\mathrm{HCl}$ and tiletamine- $\mathrm{HCl}$ (Zolatil 100, Virbac, France: mixture of $250 \mathrm{mg}$ zolazepam- $\mathrm{HCl}$ and $250 \mathrm{mg}$ tiletamine- $\mathrm{HCl})$. After injection of atropin sulfate $(0.5 \mathrm{mg} / \mathrm{head}$ or $0.5 \mathrm{mg} / 100 \mathrm{~kg}$ for larger individuals; Atropin sulfate, Tanabe, Japan) by a syringe or a blow gun, $3 \mathrm{mg} / \mathrm{kg}$ of zolazepam- $\mathrm{HCl}$ and tiletamine $-\mathrm{HCl}$ (prepared at $100 \mathrm{mg} / \mathrm{ml}$ ) were also injected by a syringe or a blow gun based on measured (captive) or estimated (wild) body weight. After confirmation of induction, body size and weight were measured, radio-transmitter and ear tags were attached, blood samples were collected, and a tooth was extracted for age determination for wild bears. For captive bears, only blood samples were taken. Times from first injection of zolazepam- $\mathrm{HCl} /$ tiletamine- $\mathrm{HCl}$ mixture to induction (defined as the time that a bear laid down its head, became sternally recumbent, and showed no response to a loud noise) were measured, and subsequent respiration rates, heart rates and rectal temperatures were recorded at approximately $19(18.6 \pm 6.4), 25(25.1 \pm$ $8.1)$ and $16(16.1 \pm 5.9)$ minutes from induction respectively. In some captive bears, time to recovery (defined as the time that a bear stands up and can walk) was noted, but this was not measured in wild bears to minimize danger to the handlers. If immobilized bears showed any signs of recovery during the handling, $1 / 3$ to $1 / 2$ volumes of the initial dose were administered by hand injection.

Table 1 summarizes data collected on dosages administered and physiological responses in both captive and wild bears. Because only blood samples were collected from most captive bears, handling time was very short and is not recorded. Immobilized bears exhibited relaxed muscles and were easy to handle. When compared with the administration of xylazine- $\mathrm{HCl}$ and ketamin- $\mathrm{HCl}(0.96 \pm 0.12 \mathrm{mg} /$ $\mathrm{kg}$ of xylazine- $\mathrm{HCl}$ and $8.76 \pm 3.42 \mathrm{mg} / \mathrm{kg}$ of ketamine- $\mathrm{HCl}$, unpublished personal data on 23 captive bears), a significantly lower dose of the zolazepam- $\mathrm{HCl} /$ tiletamine- $\mathrm{HCl}$ mixture was necessary for complete immobilization $(\mathrm{P}<0.01$, Mann-Whitney's U-test). In addition, since both zolazepam- $\mathrm{HCl}$ and tiletamine- $\mathrm{HCl}$ are highly water-soluble, the mixture 
Table 2. Recovery time of captive bears.

\begin{tabular}{ccccc}
\hline \multirow{2}{*}{ Bear } & Sex & \multicolumn{3}{c}{ Time to Recovery(min.) } \\
\cline { 3 - 5 } & & First inj. & Induction & Last inj. \\
\hline 1 & male & 56 & 35 & 20 \\
2 & male & 82 & 74 & 40 \\
3 & male & 51 & 41 & $-* 2$ \\
4 & male & 45 & 40 & - \\
5 & female & 59 & 55 & - \\
6 & male & 66 & NC & - \\
7 & male & 57 & NC & - \\
\hline Mean \pm SD & & $59 \pm 12$ & $49 \pm 16$ & $30 \pm 14$ \\
\hline
\end{tabular}

${ }^{* 1} \mathrm{NC}$ : Not clocked. ${ }^{* 2}-$ : Additional injection was not administered.

can be used in higher concentrations (maximum 500 $\mathrm{mg} / \mathrm{ml}$ ) so that small darts can still be used on larger animals [8]. Zolazepam- $\mathrm{HCl} /$ tiletamine- $\mathrm{HCl}$ mixture apparently does not crystallize in cold weather conditions as easily as does ketamine- $\mathrm{HCl}$ [5]. Respiration rate was thought to reflect the depth of immobilization better than other indices in this study, with rates of 10 to 20 breaths per minute considered to represent a safe range for handling immobilized bears. Further study is necessary to clarify the relationship between respiration rate and depth of immobilization using zolazepam- $\mathrm{HCl}$ and tiletamine- $\mathrm{HCl}$. Heart rates appeared to be higher than those recorded for the administration of xylazine $-\mathrm{HCl}$ and ketamine- $\mathrm{HCl}(59.2 \pm 13.1$, unpublished personal data on 23 captive bears), but limited sample size precludes statistical analysis. This difference in average heart rates may reflect the bradycardia associated with xylazine- $\mathrm{HCl}$ [6] .

The recovery times for 7 captive bears measured from first injection of zolazepam- $\mathrm{HCl} /$ tiletamine $-\mathrm{HCl}$ mixture, induction, and last injection are shown in Table 2. As reported for the grizzly bear, recovery phases were smooth and mimicked in reverse order (but more slowly) the signs observed during induction [9]. The recovery times measured from first injection and induction ranged from 56 to 82 minutes and from 35 to 74 minutes, respectively.
Rapid recovery from immoblization is recognized as an important consideration for animal safety, particularly when others may prey on an immobilized or slowly recovering animal. Thus, yohimbine hydrochloride is recommended as an effective antagonist to ketamine- $\mathrm{HCl}$ and xylazine- $\mathrm{HCl}$ for polar bears and black bears $[3,7]$. However, in Hokkaido, access to trapping sites can only be made on foot, so adequate time for handlers to leave the area before the bear recovers is a prior consideration. As shown in Table 2 , the recovery time from first injection seems short enough to ensure bear safety while allowing handlers enough time to leave the area safely .

We conclude that the combination of tiletamine $-\mathrm{HCl}$ and zolazepam- $\mathrm{HCl}$ is safe and effective for immobilizing Hokkaido brown bears.

\section{要約}

飼育下 20 頭抢よび野生 9 頭のエゾヒグマを対象に, 塩酸 ゾラゼパムと塩酸チレタミンの混合薬の効果と有効量を検 討した。その結果, 不動化に必要な薬用量は飼育個体で $3.52 \pm 1.53$, 野生個体では $3.75 \pm 1.57 \mathrm{mg} / \mathrm{kg}$ と十分に少 量であった。また，不動化されたクマは十分に脱力してお り，飼育個体については覚醒も速やかであった。エゾヒグ マに対してこの薬物の組み合わせが有効であることが示唆 された。

キーワード：ヒグマ, 塩酸チレタミン, 塩酸ゾラゼパム 


\section{Hifumi TSURUGA et al.}

\section{REFERENCES}

1. Addison EM. Kolenosky GB. 1979. Use of ketamine hydroch loride and xylazine hydrochloride to immobilize black bears (Ursus americanus). J Wildl Dis 15: 253-258.

2. Boever WJ. Holden J. Kane K. 1977. Use of Telazol (CI-744) for chemical restraint and anesthesia in wild and exotic carnivores. Vet Med/Sm Anim Clin 72: 1722-1725.

3. Garshelis DL. Noyce KV. Karns PD. 1987. Yohimbine as an antagonist to ketamine-xylazine immobilization in black bears. Int Conf Bear Res and Manage 7: 323-327.

4. Gibeau ML. Paquet PC. 1991. Evaluation of Telazol for immobilization of black bears. Wildl Soc Bull 19: 400-402.

5. Lee J. Schweinsburg R. Kernan F. Haigh J. 1981. Immobilization of polar bears (Ursus maritimus, PHIPPS) with ketamine hydrochloride and xylazine hydrochloride. J Wildl Dis 17: 331-336.
6. Pond DB. O'Gara BW. 1994. Chemical immobilization of large animals. pp.125-139. In: Research and Management Techniques for Wildlife and Habitats. The Wildlife Society, Maryland.

7. Ramsay MA. Stirling I. Knutsen L $\phi$. Broughton E. 1985. Use of yohimbine hydrochloride to reverse immobilization of polar bears by ketamine hydrochloride and xylazine hydrochloride. $J$ Wildl Dis 21: 396-400.

8. Schobert E. 1987. Telazol use in wild and exotic animals. Vet Med 82: 1080-1088.

9. Taylor WP. Reynolds HV. Ballard WB. 1989. Immobilization of Grizzly bears with tiletamine hydrochloride and zolazepam hydrochloride. J Wildl Manage 53: 978-981.

10. Tsubota T. Yamamoto K. Mano T. Yamanaka M. Kanagawa H. 1991. Immobilization of the free-ranging Hokkaido brown bear, Ursus arctos yesoensis with ketamine hydrochloride and xylazine hydrochloride. $J$ Vet Med Sci 53: 321-322. 